\title{
IDENTIFICATION OF THE PREVALENCE OF RISK FACTORS FOR THE DEVELOPMENT OF METABOLIC SYNDROME IN EMPLOYEES OF A FOOTWEAR COMPANY
}

\section{Laurynês de Castro; Jessica Silva Souza1; Julia Rosa Tarlé Perillo; Sarah da Silva Candido²; José Alexandre Bachur ${ }^{3}$ and Cynthia Kallás Bachur;}

\begin{abstract}
${ }^{1}$ Brazil Medical student at the University of Franca (UNIFRAN), Franca - SP - Brazil; ${ }^{2}$ Ribeirão Preto School of Nursing, University of São Paulo - USP - Ribeirão Preto - SP - Brazil; ${ }^{3}$ Professor of the Physiotherapy Course at the University of Franca -Franca - SP. - Brazil; ${ }^{4}$ Professor of the Physiotherapy and Medicine Course at the University of Franca -Franca - SP. -Brazil
\end{abstract}

\section{ARTICLE INFO}

\section{Article History:}

Received $10^{\text {th }}$ October, 2020

Received in revised form

$11^{\text {th }}$ November, 2020

Accepted $16^{\text {th }}$ December, 2020

Published online $30^{\text {th }}$ January, 2021

\section{Key Words:}

Risk Factors; Occupational Medicine;

Metabolic syndrome;

Cardiovascular diseases.

*Corresponding author: Laurynês de Castro,

\begin{abstract}
Objective: to identify the risk factors for Metabolic Syndrome in employees of a company. Methods: cross-sectional descriptive study with the participation of employees of a private shoe company, 2018. An instrument with a self-report on a socio-demographic profile was applied. Body mass index, waist circumference (WC) and blood pressure (BP) were calculated. Blood glucose values were obtained from the casual measurement by rapid tests. The behaviors of practicing physical activity were obtained from the International Physical Activity Questionnaire. The analysis was presented by descriptive statistics from mean and standard deviation, absolute and relative values. Results: 61 employees, average age 30 years. Glycemic indexes were higher among men $(97.30 \mathrm{mg} / \mathrm{dL})$. The prevalence of overweight $(46.7 \%)$ and $\mathrm{WC}(40 \%)$ were higher among women. Most workers (62.2\%) had normal BP. In both sexes, they were classified as "active". Conclusion: the present study contributes to an early performance through educational, behavioral and evaluative measures such as lectures, counseling and health assessments contributing to increased productivity and reduced health costs.
\end{abstract}

Copyright @ 2021, Laurynês de Castro, Jessica Silva Souza, Julia Rosa Tarlé Perillo, Sarah da Silva Candido, José Alexandre Bachur and Cynthia Kallás Bachur. This is an open access article distributed under the Creative Commons Attribution License, which permits unrestricted use, distribution, and reproduction in any medium, provided the original work is properly cited.

Citation: Laurynês de Castro, Jessica Silva Souza, Julia Rosa Tarlé Perillo, Sarah da Silva Candido, José Alexandre Bachur and Cynthia Kallás Bachur $\boldsymbol{o}$, 2021. "Identification of the prevalence of risk factors for the development of metabolic syndrome in employees of a footwear company" International Journal of Development Research, 11, (01), 44006-44009.

\section{INTRODUÇÃO}

Metabolic Syndrome (MS) corresponds to a disorder represented by multiple cardiovascular risk factors, the most common being central fat deposition and insulin resistance. This syndrome increases 1.5 times the overall mortality ${ }^{(1)}$. According to the National Cholesterol Education Program's Adult Treatment Panel III and the World Health Organization (WHO), the diagnosis of MS is made through the presence of at least three of the following components: abdominal obesity, diabetes mellitus (DM), dyslipidemia and arterial hypertension $(\mathrm{AH})^{(1)}$. Abdominal obesity is determined by measuring waist circumference (WC), when higher than the reference values.Regarding the lipid profile, as recommended by the Update to the Brazilian Dyslipidemia and Atherosclerosis Prevention Directive (2), triglycerides with levels above $150 \mathrm{mg} / \mathrm{dl}$ and HDL levels below $50 \mathrm{mg} / \mathrm{dL}$ in women and $40 \mathrm{mg} / \mathrm{dL}$ in men are considered. Fasting blood glucose values greater than $110 \mathrm{mg} / \mathrm{dL}$ are significant for the diagnosis of DM, however, reference values for blood glucose can be used at random, according to the Guidelines of the Brazilian Diabetes
NCEP-ATP III determines for the diagnosis of MS Systolic Arterial Pressure (SBP) values $\geq 130 \mathrm{mmHg}$ or Diastolic Blood Pressure $(\mathrm{DBP}) \geq 85 \mathrm{mmHg}{ }^{(1)}{ }^{(4)}$. The identification of risk factors for the development of MS and cardiovascular diseases is essential, since contemporary society often has incongruous lifestyle habits with a life free of comorbidities. It is notorious how modernization and urbanization influence people's eating habits, who are increasingly consuming fastfoods, which in turn are rich in sodium and hydrogenated fats. In addition, any convenience resulting from technological advances, as well as from the hectic pace of life, predisposes people to have a sedentary life ${ }^{(5)(6)(7)}$. In this context, Occupational Health aims to understand the relationships between the health-disease process and work. In this regard, the environmental and organizational risks to which they are exposed are of great importance (8). The Organic Health Law (Law $n^{\circ} 8080 / 90$ ) determines that the worker's health actions follow the general principles of the Unified Health System and recommends the inspection of the work environment and assistance to the worker ${ }^{(9)}$. The presence of comorbidities can affect the performance of workers, leading to an 
early decrease in productive life and, consequently, an economic deficit and an increase in the number of work accidents and absenteeism ${ }^{(10)}$. Therefore, with a focus on worker health, the objective of this study was to identify the prevalent risk factors for the development of Metabolic Syndrome in employees of a private footwear company.

\section{METHODS}

This is a cross-sectional study of a descriptive character, applied to employees of a private footwear company in a city in the interior of São Paulo, in 2018. Participants were invited to participate in the research and were approached in the workplace in a previously scheduled period with the owners. Everyone was informed about the objective of the work, as well as its stages and all doubts were clarified. For the assessment of the socio-demographic profile, an instrument with self-declared responses was applied, which contains the following data: gender, age, race / color, marital status, family income (in minimum wages), number of dependents and professional status. To assess the intensity of physical activity and the level of physical inactivity, the International Physical Activity Questionnaire (IPAQ), which is self-administered, developed by WHO ${ }^{(11)}$ was applied. Such a questionnaire has limitations, such as, for example, inaccuracy in responses and memory biases, on the other hand, it presents low cost and ease of application, in addition to collecting the type of activity and the context in which it occurs. Participants who performed at least 150 minutes of physical activity weekly for 5 or more days of the week were classified as physically active and sedentary those who performed less than 10 minutes of physical activity daily. Those who reported performing physical activity but did not reach the proposed recommendations were considered insufficiently active.

To measure the Body Mass Index (BMI) and classify whether or not obesity is present, the participants underwent an anthropometric assessment, with a measurement of body weight and height. This index is calculated from the value of body weight $(\mathrm{kg})$ divided by the square of height $(\mathrm{cm})^{(12)}$ A W903 digital portable scale was used, with capacity to register $180 \mathrm{~kg}$, automatic display activated with the touch of the feet positioned on a straight floor. Participants were positioned in the center of the scale base, barefoot, wearing light clothing. The height was verified with the use of a tape measure, accurate to $0.5 \mathrm{~cm}$, fixed on a smooth wall, where the participant stood, barefoot, with the heels together, back straight and arms extended at the side of the body. From the result, the BMI obtained was classified using constant values. The BMI classification is in accordance with the guidelines established in the 2016 Brazilian Obesity Guidelines ${ }^{(13)}$. They were classified as having normal weight between 20 and $24.9 \mathrm{~kg} / \mathrm{m}^{2}$, low weight when less than $20 \mathrm{~kg} / \mathrm{m}^{2}$, overweight between 25 and $29.9 \mathrm{~kg} / \mathrm{m}^{2}$; obesity between 30 and 39 $\mathrm{kg} / \mathrm{m}^{2}$; severe obesity $>40 \mathrm{~kg} / \mathrm{m}^{2}$. To obtain the Abdominal Circumference (AC) measurement, the participants remained in an upright position, with the abdomen relaxed, arms at the sides, with the feet together and their weight equally supported by both legs. The measurement was performed following the recommendation of the I Brazilian Guideline for the Diagnosis and Treatment of Metabolic Syndrome ${ }^{(1)}$ : at the midpoint between the lower costal margin and the iliac crest. In this way, the costal ridge was first located and marked with the tip of a pen. Soon after, the iliac crest was palpated on the axillary midline and marked. Finally, a measuring tape was placed horizontally on the midline between the costal margin and the iliac crest and maintained in such a way that it remains in position around the abdomen on the level of the umbilical scar, so that the circumference can be read, in the nearest millimeter. Participants were instructed to breathe normally at the time of measurement, to avoid contraction of the muscles by contained breathing. For the classification as to the presence or absence of abdominal obesity, the Guideline establishes values $>102 \mathrm{~cm}$ in men and $>88 \mathrm{~cm}$ in women (1). To classify blood glucose values, rapid glucose tests were performed using an Accu-Check Active device, with the aid of AccuCheck Active test strips and disposable Accu-Check Safe-T-Pro Uno lancets. For analysis, the test strip was inserted in the device, when the monitor turns on automatically. From then on, a drop of blood was obtained from the 3rd finger of the left hand and applied to the test strip. The results were provided in approximately 20 seconds. It is of great importance to emphasize that the tests were carried out in the morning and the values adopted as standards were obtained according to the goal of glycemic control of the Guidelines of the Brazilian Diabetes Society of the biennium 2017-2018 ${ }^{(3)}$, which informs that the normal range of blood glucose values of an adult without diabetes, at random, is greater than $200 \mathrm{mg} / \mathrm{dL}$ and the presence of unmistakable symptoms of hyperglycemia. To identify the values and classify the BP, the indirect measurement was performed. First, a nonextensible measuring tape was used to measure the circumference of the participants' arms at the midpoint between the acromion and the olecranon, in order to choose the appropriate cuff. For this study, an automatic digital BP measurement device from OMRON HEM-7200 was used, which operates the oscillometric principle as a measurement method, with the ability to measure BP and heart rate quickly and simply, with comfortable controlled inflation., without the need for pre-configuration or re-inflation.

The monitor consists of a viewfinder, and two clamps to adjust the size of the circumference of the arm $(22$ to $32 \mathrm{~cm}$ and 32 to $42 \mathrm{~cm})$, an air tube and an air plug. The diaphragm was positioned free of clothing. As a general rule, it is recommended that the width of the inflatable bag should correspond to $40 \%$ of the circumference of the limb. BP measurements were performed with the participant in a seated position, resting for 5 minutes, feet flat on the floor, uncrossed legs, empty bladder, arm extended at the fourth intercostal space, supported on a flat, solid surface and the palm of the hand facing up and the right arm was preferred, in order to avoid false readings. From the result, the BP obtained using constant values was classified. The BP classification was according to the guidelines established in the 7th Brazilian Guideline for Hypertension ${ }^{(4)}$ : they were considered normotensive when $\mathrm{SBP} \leq 120 \mathrm{mmHg}$ and $\mathrm{DBP} \leq 80 \mathrm{mmHg}$, prehypertensive (121-139 mmHg / 81-89 mmHg), Type 1 HA (140-159/ 90-99 $\mathrm{mmHg})$, type $2 \mathrm{HA}(160-179 / 100-109 \mathrm{mmHg})$, type $3 \mathrm{HA}$ (SBP $\geq 180 \mathrm{mmHg}$ and $\mathrm{DBP} \geq 110 \mathrm{mmHg}$ ). Isolated systolic hypertension (HSI) is considered to have SBP $\geq 140 \mathrm{mmHg}$ and DBP $<90 \mathrm{mmHg}$. As inclusion criteria, participants aged over 18 years were selected and registered with a formal contract with the present shoe company chosen for this study. Exclusion criteria were nonacceptance to participate in this study. All information obtained during data collection was respectively stored in Microsoft Excel software. Quantitative variables: age range, weight, height and BMI were described from the mean and standard deviation (SD), and in absolute and relative values. This study was approved by the Research Ethics Committee CAAE: ${ }^{\circ} 79372017.2 .0000 .5495$.

\section{RESULTS}

Sixty one employees participated in this study, of which $46(75.4 \%)$ are men and $15(24.6 \%)$ are women. Regarding socio-demographic characteristics, the main age group is composed of individuals aged $>$ 30 years. It is also noted that $13.3 \%$ of women have a family income of more than four minimum wages and 12 women $(80 \%)$ have an income of between one and four wages, in contrast to the values among men, $2.2 \%$ and $84.8 \%$, respectively. Table 1 shows the characterization of professionals based on sociodemographic data and prevalent risk factors for the development of cardiovascular disease. From the identification of risk factors for MS in employees, it is observed that the average of glycemic indexes among men was 97.30 $\mathrm{mg} / \mathrm{dL}$ and $88.27 \mathrm{mg} / \mathrm{dL}$ among women. The female gender did not present any alteration in glycaemia, whereas among men, one participant $(2.2 \%)$ presented glycaemia above $200 \mathrm{mg} / \mathrm{dL}$. When considering BMI values, the most significant classification among men was normality $(41.3 \%)$, being, therefore, eutrophic. However, among women, overweight has a higher prevalence with $46.7 \%$. A highly relevant data is that 2 men $(4.4 \%)$ have severe obesity. The average BMI value for men and women corresponds to $26.67 \mathrm{~kg} / \mathrm{m}^{2}$ and $23.37 \mathrm{~kg} / \mathrm{m}^{2}$, respectively. 
Table 1. Characterization of employees of a footwear company, regarding socio-demographic characteristics and prevalent risk factors for the development of cardiovascular disease, divided by sex, 2018

\begin{tabular}{|c|c|c|c|c|}
\hline Variahles & \multicolumn{4}{|c|}{ Genre } \\
\hline Variables & \multicolumn{2}{|c|}{ Female } & \multicolumn{2}{|c|}{ Male } \\
\hline Age group (years) & $\mathrm{n}$ & $\%$ & $\mathrm{n}$ & $\%$ \\
\hline $18-22$ & 0 & 0 & 0 & 0 \\
\hline $23-26$ & 1 & 6,7 & 4 & 8,5 \\
\hline $26-30$ & 5 & 33,3 & 8 & 17,4 \\
\hline$>30$ & 9 & 60 & 34 & 74,1 \\
\hline Total & 15 & 100 & 46 & 100 \\
\hline \multicolumn{5}{|l|}{ Minimum wage range } \\
\hline$<1$ & 1 & 6,7 & 6 & 13 \\
\hline $1-4$ & 12 & 80 & 39 & 84,8 \\
\hline$>4$ & 2 & 13,3 & 1 & 2,2 \\
\hline Total & 15 & 100 & 46 & 100 \\
\hline \multicolumn{5}{|l|}{ Glucose at random (mg/dL) } \\
\hline Normoglycemia & 15 & 100 & 45 & 97,8 \\
\hline Hiperglycemia & 0 & 0 & 1 & 2,2 \\
\hline Total & 15 & 100 & 46 & 100 \\
\hline \multicolumn{5}{|l|}{ BMI Classification $\left(\mathrm{kg} / \mathrm{cm}^{2}\right)$} \\
\hline Low weight & 0 & 0 & 1 & 2,2 \\
\hline Normality & 6 & 40 & 19 & 41,3 \\
\hline Overweight & 7 & 46,7 & 18 & 39,1 \\
\hline Obesity & 2 & 13,3 & 6 & 13 \\
\hline Severy obesity & 0 & 0 & 2 & 4,4 \\
\hline Total & 15 & 100 & 46 & 100 \\
\hline \multicolumn{5}{|l|}{ Abdominal circumference $(\mathrm{cm})$} \\
\hline $\begin{array}{l}\text { Normal } \quad(<88 \mathrm{~cm} \text { for women } \\
\text { and }<102 \mathrm{~cm} \text { for men })\end{array}$ & 9 & 60 & 37 & 80,4 \\
\hline $\begin{array}{l}\text { High }(>88 \mathrm{~cm} \text { for women and }>102 \mathrm{~cm} \\
\text { for men) }\end{array}$ & 6 & 40 & 9 & 19,6 \\
\hline Total & 15 & 100 & 46 & 100 \\
\hline \multicolumn{5}{|l|}{ BP classification ( $\mathrm{mmHg}$ ) } \\
\hline Normal & 13 & 86,7 & 25 & 54,3 \\
\hline Pre hypertension & 0 & 0 & 7 & 15,2 \\
\hline HA stage 1 & 0 & 0 & 2 & 4,4 \\
\hline HA stage 2 & 0 & 0 & 1 & 2,2 \\
\hline HA stage 3 & 0 & 0 & 0 & 0 \\
\hline HSI & 2 & 13,3 & 11 & 23,9 \\
\hline Total & 15 & 100 & 46 & 100 \\
\hline \multicolumn{5}{|l|}{ IPAQ } \\
\hline Sedentary & 2 & 13,3 & 11 & 24 \\
\hline Insufficient Active & 5 & 33,3 & 11 & 24 \\
\hline Active & 8 & 53,4 & 20 & 43,5 \\
\hline Very Active & 0 & 0 & 4 & 8,5 \\
\hline Total & 15 & 100 & 46 & 100 \\
\hline
\end{tabular}

$\mathrm{mg} / \mathrm{dL}=$ milligrams per deciliter; $\mathrm{Kg}=$ kilogram; $\mathrm{cm}=$ centimeter; $\mathrm{mmHg}=$ Millimeters of Mercury.

Table 2. Distribution of employees of a footwear company according to the Average and Standard Deviation in $\mathrm{mmHg}$ of the values of Systolic Blood Pressure (SBP) and Diastolic Blood Pressure (DBP) divided by sex, 2018

\begin{tabular}{lll}
\hline Variables & Genre & \\
\cline { 2 - 3 } & $\begin{array}{l}\text { Female } \\
\text { Average } \pm \mathrm{SD}\end{array}$ & $\begin{array}{l}\text { Male } \\
\text { Average } \pm \mathrm{SD}\end{array}$ \\
\hline $\mathrm{SBP}(\mathrm{mmHg})$ & $120,73 \pm 16,85$ & $130,67 \pm 19,87$ \\
$\mathrm{DBP}(\mathrm{mmHg})$ & $74,13 \pm 14,49$ & $72,83 \pm 10,82$ \\
\hline $\mathrm{mmHg}=$ Millimeters of Mercury; $\mathrm{SD}=$ Standard Deviation
\end{tabular}

Analyzing the abdominal circumference measurements, it is found that $6(40 \%)$ of the women present values higher than that considered appropriate for sex, while this value among men corresponds to 9 (19.6\%). The average of these values for women is $81.93 \mathrm{~cm}$ and for men it is $91.48 \mathrm{~cm}$. Regarding BP measurements, $25(54.3 \%)$ men and $13(86.7 \%)$ women had normal blood pressure levels. No candidate was classified as hypertensive in stage 3, however $10(21.8 \%)$ men were classified in the categories between prehypertension and HA stage 2 , contrasting with the result of $0 \%$ of women with these classifications. HSI occurs in $11(23.9 \%)$ men and $2(13.3 \%)$ women. Table 2 shows the mean values of the Systolic Blood Pressure (SBP) and Diastolic Blood Pressure (DBP) and the Standard Deviation (SD) for each sex. The mean SBP was higher in males, but the DBP was greater in females. Regarding the results obtained in the IPAQ questionnaire. The most representative level of physical activity was active for both sexes (53.4\% of women and $43.5 \%$ of men). However, the number of sedentary employees found was 2 women $(13.3 \%)$ and 11 men (24\%). The distribution of the means and standard deviation of the blood glucose, waist circumference and BMI of the employees are shown in Table 3.

Table 3. Distribution of employees of a footwear company according to the Average and Standard Deviation of blood glucose ( $\mathrm{mg} / \mathrm{dl}$ ), waist circumference $(\mathrm{cm})$ and BMI $\left(\mathrm{kg} / \mathrm{m}^{2}\right)$ divided by sex, 2018

\begin{tabular}{lll}
\hline Variables & Genre & \\
\cline { 2 - 3 } & Female & Male \\
& Average $\pm \mathrm{SD}$ & Average $\pm \mathrm{SD}$ \\
Blood glucose $(\mathrm{mg} / \mathrm{dl})$ & $89,27 \pm 12,85$ & $97,30 \pm 23,49$ \\
Abdominal circumference $(\mathrm{cm})$ & $81,93 \pm 9,71$ & $91,48 \pm 12,15$ \\
Body mass index $\left(\mathrm{kg} / \mathrm{m}^{2}\right)$ & $23,37 \pm 2,99$ & $26,67 \pm 4,53$ \\
\hline
\end{tabular}

$\mathrm{mg} / \mathrm{dL}=$ milligrams per deciliter; $\mathrm{Kg}=$ kilogram; $\mathrm{cm}=$ centimeter; $\mathrm{mmHg}=$ Millimeters of Mercury.

The results obtained in the two stages of the project allowed feedback to all participants after the procedures carried out in the second stage, on the awareness of changes in lifestyle habits, in an attempt to prevent future cardiac events. In the end, informative and educational booklets were distributed to each participant on all the themes worked on. The doubts presented by the participants were immediately clarified in simple and accessible language.

\section{DISCUSSION}

This study indicates the existence of some risk factors for MS among workers in the analyzed industry, which is in agreement with the results of other studies. In a study with the objective of identifying cardiovascular risk factors in workers in an industry in a city in the state of São Paulo (5), 16\% of the sample were classified as obese and $46 \%$ as overweight, these results being close to obtained in this study that $16.4 \%$ of the sample are obese and $41 \%$ overweight. Regarding the BP values, a higher percentage of hypertensive $(28 \%)$ and prehypertensive $(45 \%)$ individuals was obtained as a result than in the present study; a higher percentage of normotensive individuals $(62.3 \%)$ was obtained than hypertensive $(4.92 \%)$ and prehypertensive $(11.48 \%)^{(5)}$. Another divergence occurs in relation to the glycemic values that were more significant among women $(10 \%)$ with total prevalence among the sample of $9 \%$ and in the present study it was more expressive among men. Regarding physical activity levels, $21.3 \%$ of workers are considered sedentary ${ }^{(5)}$. Another study that assessed risk factors for MS in workers in an oil industry quantified $41.3 \%$ sedentary ${ }^{(14) .}$ Two systematic literature reviews, from 2012 and 2017, point out the importance of integrating Health Promotion practices within the scope of Occupational Health, being in agreement and corroborating to justify the relevance of this work. They declare that such activities contribute to raising people's awareness of behavioral changes and good health practices. This can occur through educational, behavioral and evaluative measures such as lectures, counseling and health assessments. They have the benefit of identifying risk factors for early performance, contributing to increase the company's productivity and decrease health costs ${ }^{(15)(16) .}$

\section{CONCLUSION}

Based on the data from the present study, it is suggested that the evaluation and identification of risk factors for the development of Metabolic Syndrome is an effective and convenient proposal, since, actions like these, allow the implementation of educational interventions as well as contribute to the modification behavioral, productivity and quality of life of workers.

\section{REFERENCES}

Sociedade Brasileira de Hipertensão, Sociedade Brasileira de Cardiologia, Sociedade Brasileira de Endocrinologia e Metabologia, Sociedade Brasileira de Diabetes, Associação Brasileira para Estudos da Obesidade. I Diretriz Brasileira de 
Diagnóstico e Tratamento de Síndrome Metabólica. Diretriz. São Paulo:; 2005.

Faludi AA, Izar MCO, Saraiva JFK, Chacra APM, Bianco HT, Afiune Neto A, Bertolami A, Pereira AC. Atualização da Diretriz Brasileira de Dislipidemias e Prevenção da Aterosclerose. Arquivo Brasileiro de Cardiologia. 2017 Agosto: p. 21-22.

Organização José Egídio Paulo de Oliveira, Renan Magalhães Montenegro Junior, Sérgio Vencio. Diretrizes da Sociedade Brasileira de Diabetes de 2017-2018 São Paulo: Clannad; 2017.

MVB Malachias; RMS Póvoa; AR Nogueira; D Souza; LS Costa; ME Magalhães. $7^{\mathrm{a}}$ Diretriz Brasileira de Hipertensão Arterial. Arquivos Brasileiros de Cardiologia. 2016 Setembro: p. 103.

Roberta Soares Lara Cassani, Fernando Nobre, Antônio Pazin Filho, André Schmidt. Prevalência de Fatores de Risco Cardiovascular em Trabalhadores de uma Indústria Brasileira. Arquivo Brasileiro de Cardiologia. 2009 Janeiro: p. 16-22.

Edilaine Monique de Souza Carlucci; José Alípio Garcia Gouvêa; Ana Paula de Oliveira; Joseane Dorneles da Silva; Angélica Capellari Menezes Cassiano; Rose Mari Bennemann. Obesidade e sedentarismo: fatores de risco para doença cardiovascular. Com. Ciências Saúde. 2013 setembro: p. 375-384.

Cristina Pinheiro Mendonça; Luiz Antonio dos Anjos. Aspectos das práticas alimentares e da atividade física como determinantes do crescimento do sobrepeso/obesidade no Brasil. Cadernos de Saúde Pública. 2004 Maio-Junho: p. 698-709.
Saúde Md. Cadernos de Atenção Básica - №5. Brasília: Secretaria de Políticas de Saúde, Departamento de Atenção Básica; 2002.

República Pd. LEI No 8.080, DE 19 DE SETEMBRO DE 1990. [Online].; 1990 [cited 2018 Agosto 22. Available from: http://www.planalto.gov.br/ccivil_03/Leis/L8080.htm.

Tatiane Paschoal; Álvaro Tamayo. Validação da Escala de Estresse no Trabalho. Estudos de Psicologia. 2004 Fevereiro: p. 8.

Sandra Matsudo; Timoteo Araujo; Victor Matsudo; Douglas Andrade; Erinaldo Andrade; Luis Carlos Oliveira; Glaucia Braggion. Questionário internacional de atividade física (IPAQ): estudo de validade e reprodutibilidade no Brasil.. Revista Brasileira de Atividade Física e Saúde. 2001; 6(2).

Omero Francisco Bertol; Géri Natalino Dutra; Percy Nohama. Sistema para calcular e classificar o Índice de Massa Corporal de índivíduos adultos..

Associação Brasileira para o Estudo da Obesidade e da Síndrome Metabólica. Diretrizes brasileiras de obesidade 2016. 2016.

Felipe-de-Melo ERT, Silva RdCRd. Fatores associados à síndrome metabólica em trabalhadores administrativos de uma indústria de petróleo. Ciência \& Saúde Coletiva. 2011; 16(8).

Carvalho AFS, Dias EC. Pomoção de saúde no local de trabalho: Revisão sistemática da literatura. Revista Brasileira de Promoção de Saúde. 2012 Janeiro-Março; 25(1).

Hipólito MCV, Masson VA, Monteiro MI, Gutierrez GL. Qualidade de vida no trabalho: avaliação de estudos de intervenção. Revista Brasileira de Enfermagem. 2017 Janeiro-Fevereiro; 70(1). 